\title{
HUBUNGAN ANTARA MINAT MENJADI TEKNISI DENGAN SIKAPNYA TERHADAP PEKERJAAN TEKNISI OTOMOTIF PADA SISWA SMK
}

\author{
Eka A. Saefudin ${ }^{1}$, Iwa Kuntadi ${ }^{2}$, Tatang Permana ${ }^{3}$ \\ Departemen Pendidikan Teknik Mesin, FPTK UPI \\ Jl. Dr. Setiabudhi No.207 Bandung 40154 \\ eka.asyarullah90@gmail.com
}

\begin{abstract}
ABSTRAK
Penelitian ini bertujuan untuk mengetahui hubungan antara minat menjadi teknisi otomotif dengan sikap terhadap pekerjaan teknisi otomotif pada siswa kelas XII TKR SMK Negeri 1 Cilaku. Metode yang digunakan dalam penelitian ini adalah metode deskriptif studi korelasional, dengan teknik pengumpulan data berupa angket. Berdasarkan hasil pengolahan data menunjukkan bahwa tingkat minat menjadi teknisi otomotif termasuk dalam kategori tinggi, dan sikap terhadap pekerjaan teknisi otomotif termasuk kedalam kategori tinggi atau sikap positif. Berdasarkan hasil analisis diperoleh hasil pengujian korelasi antara minat menjadi teknisi otomotif dengan sikap terhadap pekerjaan teknisi otomotif sebesar 0,79, angka tersebut menunjukkan hubungan antara minat menjadi teknisi otomotif dengan sikap terhadap pekerjaan teknisi otomotif pada siswa kelas XII TKR SMK Negeri 1 Cilaku pada kategori tinggi.
\end{abstract}

Kata kunci: minat, sikap, teknisi otomotif.

\section{PENDAHULUAN}

Perwujudan nyata dari pendidikan di Indonesia adalah terlaksananya proses belajar mengajar (PBM) disekolah, sebagai contoh terlaksananya pembelajaran di SMK. SMK merupakan lembaga pendidikan formal yang mempersiapkan siswanya untuk menjadi tenaga kerja tingkat menengah yang memiliki pengetahuan, keterampilan dan sikap sebagai juru teknik, sehingga lulusan SMK diharapkan memiliki kemampuan dan keterampilan yang sesuai dengan kebutuhan dunia industri. SMK Negeri 1 Cilaku merupakan sekolah menengah kejuruan yang telah banyak mencetak tenaga kerja yang terampil dan mampu bersaing dipasar kerja. Hal tersebut dapat dilihat dari banyaknya lulusan yang terserap oleh industri yang ada di Indonesia.

\footnotetext{
${ }^{1}$ Mahasiswa Departemen Pendidikan Teknik Mesin FPTK UPI

${ }^{2}$ Dosen Departemen Pendidikan Teknik Mesin FPTK UPI

${ }^{3}$ Dosen Departemen Pendidikan Teknik Mesin FPTK UPI
} 
Tabel 1. Persentase Jumlah Lulusan yang Diserap oleh Industri

\begin{tabular}{llccccc}
\hline Tahun lulus & Jurusan & $\begin{array}{c}\text { Jumlah } \\
\text { Lulusan }\end{array}$ & $\begin{array}{c}\text { Jumlah } \\
\text { Melanjutkan }\end{array}$ & $\begin{array}{c}\text { Jumlah } \\
\text { Siap Kerja }\end{array}$ & $\begin{array}{c}\text { Jumlah } \\
\text { Disalurkan }\end{array}$ & Persentase \\
\hline $2009-2010$ & TGB & 53 & 15 & 38 & 35 & $92,11 \%$ \\
& TITL & 65 & & 65 & 61 & $93,85 \%$ \\
& TP & 63 & & 63 & 61 & $96,83 \%$ \\
& TKR & 63 & & 63 & 57 & $90,48 \%$ \\
$2010-2011$ & TGB & 56 & 6 & 50 & 45 & $90 \%$ \\
& TITL & 65 & & 65 & 61 & $93,85 \%$ \\
& TP & 66 & 2 & 64 & 57 & $89,06 \%$ \\
$2011-2012$ & TKR & 55 & 2 & 53 & 51 & $96,23 \%$ \\
& TGB & 57 & 7 & 50 & 31 & $62 \%$ \\
& TITL & 67 & 2 & 65 & 41 & $63,01 \%$ \\
& TP & 62 & & 62 & 33 & $53,23 \%$ \\
Jumlah & TKR & 66 & & 66 & 33 & $50 \%$ \\
& & 734 & 34 & 704 & 566 & $80,40 \%$ \\
\hline
\end{tabular}

Lulusan SMK kelak akan memasuki dunia kerja (Tabel 1), harapannya lulusan SMK dapat diserap seluruhnya oleh perusahaan-perusahaan yang sesuai dengan bidang keahliannya. Khusus bidang keahlian TKR, pekerjaan yang relevan dengan bidang keahliannya yaitu sebagai teknisi otomotif, akan tetapi pada kenyataannya lulusan TKR tidak semua bekerja sebagai teknisi di bidang otomotif (Tabel 2).

Tabel 2. Jumlah lulusan jurusan TKR yang bekerja menjadi teknisi otomotif

\begin{tabular}{cccc}
\hline Tahun Lulusan & Jumlah siswa & $\begin{array}{c}\text { Yang bekerja menjadi } \\
\text { teknisi otomotif }\end{array}$ & $\begin{array}{c}\text { Persentase } \\
(\%)\end{array}$ \\
$2010-2011$ & 55 & 22 & $40 \%$ \\
$2011-2012$ & 66 & 13 & $20 \%$ \\
\hline
\end{tabular}

Hal tersebut dipengaruhi oleh beberapa faktor diantaranya terbatasnya lapangan kerja, melanjutkan pendidikan ke perguruan tinggi, berwirausaha dan memilih bekerja dibidang lain selain dibidang otomotif. Fenomena keberagaman pilihan yang dialami lulusan SMK dipengaruhi oleh beberapa faktor yaitu faktor ekonomi, pengaruh lingkungan keluarga, kemampuan akademik, minat, prospek serta pengalaman dan kemahiran. Berdasarkan faktor-faktor tersebut, minat rupa-rupanya merupakan faktor penting untuk dikaji lebih mendalam. Minat adalah gejala psikologis yang menunjukan pemusatan perhatian terhadap suatu obyek sebab ada perasaan senang (Haryanto,2010). 
Berdasarkan hasil observasi awal dengan menyebar instrument ke beberapa siswa jurusan TKR di SMK Negeri 1 Cilaku, diperoleh hasil bahwa 57,5\% dari 30 siswa menyatakan berminat bekerja menjadi seorang teknisi otomotif sedangkan 42,5\% menyatakan tidak berminat menjadi seorang teknisi. Hasil tersebut lebih dari setengah responden dalam hal ini siswa menyatakan berminat menjadi seorang teknisi akan tetapi minat dari siswa menjadi teknisi masih tergolong belum maksimal dan belum menunjukan pencapaian yang masimal dari apa yang diharapkan sekolah. Hasil 57,5\% yang menyatakan berminat menjadi teknisi otomotif masuk kedalam kategori rendah. Minat yang beragam ini akan mempengaruhi sikap seseorang terhadap suatu profesi pekerjaan terutama pekerjaan teknisi otomotif.

Sikap seseorang terhadap pekerjaan teknisi otomotif dapat terbentuk dari apa yang mereka pelajari, alami, sesuatu yang mereka sukai atau tidak mereka sukai serta sikap yang positif terhadap suatu obyek akan memberikan nilai yang berharga dan istimewa terhadap apa yang menjadi pilihannya. Siswa memiliki keinginan untuk mencapai cita-cita berdasarkan minat yang mereka jalani sesuai dengan ilmu yang mereka dapat pada saat sekolah. uraian diatas menunjukkan adanya hubungan antara minat dengan sikap.

Berpijak pada latar belakang masalah di atas maka penelitian ini betujuan untuk: 1) mengetahui seberapa besar tingkat minat bekerja menjadi teknisi otomotif pada siswa TKR kelas XII di SMK Negeri 1 Cilaku. 2) mengetahui seberapa besar tingkat sikap terhadap pekerjaan teknisi otomotif pada siswa TKR kelas XII di SMK Negeri 1 Cilaku. 3) mengetahui sejauhmana hubungan antara minat menjadi teknisi otomotif dengan sikapnya terhadap pekerjaan teknisi otomotif pada siswa TKR kelas XII di SMK Negeri 1 Cilaku. Minat adalah pemusatan pikiran, perhatian dan perasaan yang menimbulkan ketertarikan terhadap orang, benda, aktivitas dan situasi, sehingga mempengaruhi gerak untuk melakukan segala segala sesuatu dalam mewujudkan pencapain tujuannya.

Banyak faktor yang mempengaruhi minat seseorang terhadap obyek atau aktivitas tertentu, berikut merupakan faktor-faktor yang dapat mempengaruhi minat. Faktor yang mempengaruhi minat, Surya (1979:43) adalah faktor dari dalam (internal), meliputi: faktor fisiologi/jasmani individu, yang bersifat bawaan, seperti penglihatan, pendengaran, struktur tubuh, dan sebagiannya; faktor psikologi, baik yang bersifat bawaan maupun herediter, yang terdiri atas; faktor intelektual, yang terdiri atas faktor potensial, yaitu kecerdasan dan bakat, serta faktor aktual atau kecakapan nyata, yaitu achievement atau prestasi; faktor non intelektual, yaitu 
komponen kepribadian tertentu seperti sikap, kebiasaan, kebutuhan, motivasi, konsep diri, emosional, dan sebagaiannya; faktor kematangan, baik fisik maupun psikis. Faktor dari luar (external), meliputi: faktor sosial, yang terdiri atas faktor lingkungan keluarga; faktor budaya, seperti adat istiadat, ilmu pengetahuan dan sebagainya; faktor lingkungan fisik, seperti fasilitas rumah, fasilitas belajar, iklim, dan sebagainya; faktor spiritual dan keagamaan.

Minat pada suatu bidang tertentu akan memunculkan perhatian yang spontan terhadap bidang tersebut, minat pada seseorang tidak dibawa sejak lahir melainkan terbentuk karena faktor yang mempengaruhi, baik itu faktor dari dalam seperti: keinginan, kemampuan, perasaan senang dan tingkal laku, maupun faktor dari luar seperti lingkungan tempat individu tinggal. Minat dapat dikatakan sebagai dorongan kuat bagi seseorang untuk melakukan segala sesuatu dalam mewujudkan pencapaian tujuan dan cita-cita yang menjadi keinginannya sehingga membuat seseorang akan memberikan perhatian lebih terhadap obyek yang diminatinya.

Berkaitan dengan jenis pekerjaan, dalam hal ini pekerjaan teknisi otomotif, seorang siswa yang mempunyai minat untuk menjadi teknisi otomotif akan menyenangi jenis pekerjaan tersebut, dengan minat yang kuat maka siswa akan memberikan perhatian yang tinggi terhadap pekerjaan tersebut sehingga siswa itu dapat mengembangkan dirinya lewat pembelajaran dan berusaha mempelajari tentang segala sesuatu hal yang berhubungan dengan teknisi otomotif.

Sikap adalah perwujudan dari pikiran, perasaan, serta penilaian terhadap suatu obyek psikologis sehingga menghasilkan suatu stimulus untuk bertindak terhadap obyek tersebut. Sikap mengandung tiga komponen yaitu komponen kognitif, komponen afektif, dan komponen konatif (Azwar, 1997). Sikap seseorang terhadap pekerjaan teknisi, komponen kognitif berhubungan dengan kepercayaan/keyakinan seseorang terhadap pekerjaan teknisi itu sendiri Komponen afektifnya berhubungan dengan perasaan seseorang terhadap pekerjaan teknisi apakah menyenangi jenis pekerjaan tersebut atau tidak menyenangi pekerjaan. Komponen konatifnya berhubungan dengan apa yang seseorang lakukan untuk mencapai tujuannya dalam hal ini pekerjaan teknisi. Ketiga komponen tersebut dapat dijadikan indikator dalam penelitian ini untuk mengungkap sikap siswa terhadap pekerjaan teknisi otomotif. Minat merupakan kecenderungan seseorang untuk memberikan perhatian terhadap orang, benda, aktivitas atau situasi tertentu dengan disertai perasaan senang yang mempengaruhi gerak dan kehendak untuk melakukan segala sesuatu dalam mewujudkan pencapain tujuannya, minat sangat mempengaruhi seseorang dalam mengambil sebuah keputusan, keputusan dalam hal ini sikap. 
Minat adalah sesuatu yang pribadi dan berhubungan erat dengan sikap (Suparyanto, 2011). Minat dan sikap merupakan dasar bagi prasangka dan minat juga memiliki peranan penting dalam mengambil sebuah keputusan. Minat sering dihubungkan dengan sikap dan menjadi dasar prasangka terhadap suatu hal (Cosynook, 2013). Beberapa pendapat di atas menegaskan bahwa minat erat hubungannya dengan sikap, minat bisa muncul dengan tidak disengaja, tanpa ada paksaan dari pihak luar.

\section{METODE PENELITIAN}

Metode yang digunakan dalam penelitian ini adalah metode deskriptif korelasi. Metode deskriptif studi korelasi yaitu metode yang mempelajari hubungan dua variabel atau lebih, yakni sejauh mana variasi dalam satu variabel berhubungan dengan variasi dalam variabel lain. Penelitian ini bertujuan mencari hubungan antara 2 variabel yaitu variabel minat menjadi teknisi otomotif dan variabel sikap terhadap pekerjaan teknisi otomotif. Data yang diperoleh kemudian di deskripsikan.

Pengambilan sampel dilakukan dengan menggunakan teknik sampling purposive. Sampel dalam penelitian ini adalah siswa kelas XII jurusan TKR di SMK Negeri 1 Cilaku dengan jumlah 51 siswa. Pengumpulan data yang digunakan dalam penelitian ini adalah angket. Data yang terkumpul selanjutnya diuji validitas dan realibilitasnya. Data dalam bentuk ordinal diubah ke dalam bentuk interval dengan menggunakan Methods of Successive Interval (MSI). Teknik analisi data dalam penelitian ini menggunakan korelasi produc momen, uji regresi sederhana, uji determinasi.

\section{HASIL PENELITIAN}

Hasil menunjukkan penelitian bahwa skor ideal rata-rata minat siswa menjadi teknisi otomotif (Tabel 3) yaitu sebesar 3,83. Data ini tergolong ke dalam kategori tinggi, ada 30 siswa tergolong kedalam minat kategori tinggi, hal tersebut menunjukkan bahwa mayoritas siswa kelas XII TKR di SMK Negeri 1 Cilaku memiliki minat yang tinggi untuk menjadi teknisi otomotif. 
Tabel 3. Data Minat Menjadi Teknisi Otomotif

\begin{tabular}{cccc}
\hline Rentang skor & Kategori & Frekuensi & Persentase $(\%)$ \\
$1,0-1,7$ & Sangat Rendah & 0 & $0 \%$ \\
$1,8-2,5$ & Rendah & 3 & $6 \%$ \\
$2,6-3,3$ & Sedang & 5 & $10 \%$ \\
$3,4-4,1$ & Tinggi & 30 & $59 \%$ \\
$4,2-5,0$ & Sangat Tinggi & 13 & $25 \%$ \\
& Jumlah & 51 & $100 \%$ \\
\hline
\end{tabular}

Adapun untuk mengetahui tingkap sikap terhadap pekerjaan teknisi otomotif, peneliti menggunakan angket sikap yang terdiri dari 34 item pernyataan kepada 51 siswa SMK Negeri 1 Cilaku. Berikut Gambaran mengenai sikap terhadap pekerjaan teknisi otomotif pada siswa kelas XII TKR SMK Negeri 1 Cilaku (Tabel 4).

Tabel 4. Data Sikap Terhadap Pekerjaan Teknisi Otomotif

\begin{tabular}{cccc}
\hline Rentang skor & Kategori & Frekuensi & Persentase $(\%)$ \\
$1,0-1,7$ & Sangat Rendah & 0 & $0 \%$ \\
$1,8-2,5$ & Rendah & 1 & $2 \%$ \\
$2,6-3,3$ & Sedang & 9 & $18 \%$ \\
$3,4-4,1$ & Tinggi & 31 & $61 \%$ \\
$4,2-5,0$ & Sangat Tinggi & 10 & $19 \%$ \\
& Jumlah & 51 & $100 \%$ \\
\hline
\end{tabular}

Skor ideal rata-rata sikap terhadap pekerjaan teknisi otomotif teknisi (Tabel 4) yaitu sebesar 3,67. Data ini tergolong ke dalam kategori tinggi, ada 31 siswa memiliki sikap yang tergolong tinggi atau sikap yang positif terhadap pekerjaan teknisi otomotif, hal tersebut menunjukkan bahwa mayoritas siswa kelas XII TKR SMK Negeri 1 Cilaku memiliki sikap yang positif terhadap pekerjaan teknisi otomotif.

Berdasarkan hasil pengujian hipotesis diketahui bahwa nilai koefisien korelasi pearson antara variabel minat menjadi teknisi otomotif $(\mathrm{X})$ dengan variabel sikap terhadap pekerjaan teknisi otomotif (Y) sebesar 0,792. Hasil korelasi tersebut berada dalam kategori kuat dengan arah hubungan yang linear positif.

Keberartian regresi diketahui bahwa nilai sigifikan $0,00<0,05$. Hasil tersebut menunjukkan bahwa Ho ditolak dan Ha diterima, sehingga dapat diartikan koefisien regresi 
signifikan atau minat bekerja menjadi teknisi benar-benar berhubungan dengan sikap terhadap pekerjaan teknisi.

Uji signifikan korelasi diketahui bahwa variabel minat menjadi teknisi (X) memiliki $t_{\text {hitung }}>t_{\text {Tabel }}(9,752>1,675)$. Hasil tersebut dapat diartikan yakni menolak Ho dan menerima Ha. Ini berarti bahwa minat menjadi teknisi $(\mathrm{X})$ berpengaruh signifikan terhadap sikap terhadap pekerjaan teknisi otomotif (Y).

Berdasarkan perhitungan koefisien determinasi didapat koefisien determinasi sebesar 0,63 atau 63\%. Hasil tersebut menunjukkan kedalam kategori tinggi. Besarnya nilai determinasi menunjukkan bahwa besarnya kontribusi atau pengaruh minat menjadi teknisi otomotif (X) terhadap variabel sikap terhadap pekerjaan teknisi otomotif (Y).

\section{PEMBAHASAN}

Hasil yang diperoleh dari penelitian menunjukkan bahwa minat bekerja menjadi teknisi otomotif di kalangan siswa kelas XII TKR SMK Negeri 1 Cilaku, dari 51 siswa didapat hasil sebanyak 3 siswa (6\%) termasuk kedalam kategori yang memiliki minat rendah, 5 siswa (10\%) termasuk kedalam kategori yang memiliki minat sedang, 30 siswa (59\%) termasuk kedalam kategori siswa yang memiliki minat tinggi dan 13 siswa (25\%) termasuk ke dalam kategori siswa yang memiliki minat sangat tinggi, jika dilihat dari rata-rata skor ideal yaitu sebesar 3,83 nilai tersebut termasuk kedalam kategori tinggi. Data tersebut merupakan temuan yang menunjukkan sebagai gambaran atau tingkat minat menjadi teknisi otomotif di kalangan siswa kelas XII TKR SMK Negeri 1 Cilaku itu tinggi.

Data di atas menunjukkan bahwa tingkat minat siswa menjadi teknisi tergolong kedalam kategori tinggi, minat yang tinggi tersebut muncul tidak dibawa sejak lahir melainkan terbentuk karena proses pertumbuhan dan perkembangan siswa. Faktor yang mempengaruhi minat yaitu kebutuhan, keinginan dan cita-cita, pengaruh kebudayaan dan lingkungan, kesempatan dan pengalaman seseorang.

Lingkungan sekolah merupakan salah satu faktor yang dapat mempengaruhi minat seseorang. SMK Negeri 1 Cilaku merupakan sekolah yang memiliki tujuan mencetak lulusan SMK yang terampil dan mampu bersaing dipasar kerja, siswa SMK Negeri 1 Cilaku khusus pada jurusan TKR diarahkan atau dicetak untuk menjadi teknisi dibidang otomotif, dengan bekal 
pengetahuan selama proses belajar disekolah yang didukung oleh sarana serta pengalaman mengikuti kegiatan yang berhubungan dengan otomotif, maka akan menumbuhkan minat siswa untuk bekerja menjadi teknisi otomotif, dan ketika seorang siswa yang mempunyai minat untuk menjadi teknisi otomotif akan menyenangi jenis pekerjaan tersebut, dengan minat yang kuat maka siswa akan memberikan perhatian yang tinggi terhadap pekerjaan tersebut sehingga siswa itu dapat mengembangkan dirinya lewat pembelajaran dan berusaha mempelajari tentang segala sesuatu hal yang berhubungan dengan teknisi otomotif.

Hasil yang diperoleh dari penelitian menunjukkan bahwa sikap terhadap pekerjaan teknisi otomotif di kalangan siswa kelas XII TKR SMKN 1 Cilaku dari 51 siswa didapat hasil sebanyak 1 siswa (2\%) termasuk kedalam kategori yang memiliki sikap yang rendah, 9 siswa (18\%) termasuk kedalam kategori yang memiliki sikap yang sedang, 31 siswa (61\%) termasuk ke dalam kategori siswa yang memiliki sikap yang tinggi dan 10 siswa (19\%) termasuk ke dalam kategori siswa yang memiliki sikap yang sangat tinggi, jika dilihat dari rata-rata skor ideal yaitu sebesar 3,67 nilai tersebut termasuk kedalam kategori tinggi. Data tersebut merupakan temuan yang menunjukkan sebagai gambaran atau tingkat sikap terhadap pekerjaan teknisi otomotif di kalangan siswa kelas XII TKR SMK Negeri 1 Cilaku itu tinggi artinya mayoritas dari siswa memiliki sikap yang positif terhadap pekerjaan teknisi otomotif.

Sikap terbentuk tidak dengan sendirinya, akan tetapi dipengaruhi oleh berbagai faktor. Faktor yang mempengaruhi sikap yaitu pengalaman pribadi, pengaruh orang lain yang dianggap penting, pengaruh kebudayaan, media massa, lembaga pendidikan dan faktor emosional (Azwar, 1997). Faktor lembaga pendidikan memiliki peranan penting dalam pembentukan sikap siswa terhadap suatu pekerjaan, sikap siswa terhadap suatu jenis pekerjaan dapat tercermin dari kognitif (kepercayaan), afektif (kepuasan), dan konatif (perilaku) yang positif terhadap pekerjaan tersebut.

Sikap siswa terhadap pekerjaan teknisi otomotif terbentuk pada saat proses pendidikan disekolah, siswa yang memiliki sikap positif terhadap pekerjaan teknisi otomotif, maka sudah barang tentu ketika siswa sudah bekerja sebagai teknisi akan menjalankan fungsi dan kedudukannya sebagai tenaga teknisi dengan penuh rasa tanggung jawab. Demikian pula sebaliknya, seorang siswa yang memiliki sikap negatif terhadap jenis pekerjaan teknisi otomotif, pastilah dia hanya menjalankan fungsi dan kedudukannya sebatas rutinitas belaka. Maka dari itu, amatlah perlu kiranya ditanamkan sikap positif terhadap pekerjaan yang diminatinya. 
Hasil penelitian, diketahui bahwa minat menjadi teknisi memiliki nilai regresi sebesar 0,57, nilai korelasi terhadap sikap terhadap pekerjaan teknisi otomotif sebesar 0,792 . Sehingga dapat diartikan menolak Ho dan menerima Ha. Berdasarkan temuan hasil penelitian menunjukkan bahwa minat menjadi teknisi memiliki hubungan positif dan signifikan dengan sikap terhadap pekerjaan teknisi otomotif, dan diketahui bahwa nilai $\mathrm{R}^{2}$ sebesar 0,63 atau $63 \%$. Angka tersebut menunjukkan bahwa besarnya pengaruh variabel minat menjadi teknisi otomotif terhadap variabel sikap terhadap pekerjaan teknisi otomotif adalah sebesar $63 \%$, sedangkan sisanya $37 \%$ dipengaruhi oleh variabel lain yang tidak dianalisis dalam model.

Minat merupakan kecenderungan seseorang untuk memberikan perhatian terhadap orang, benda, aktivitas atau situasi tertentu dengan disertai perasaan senang yang mempengaruhi gerak dan kehendak untuk melakukan segala sesuatu dalam mewujudkan pencapain tujuannya, minat sangat mempengaruhi seseorang dalam mengambil sebuah keputusan, keputusan dalam hal ini sikap.

Minat erat hubungannya dengan sikap, minat yang muncul dengan memberikan suatu perhatian akan menimbulkan sikap dengan perasaan senang atau tidak senang, keinginan untuk memperoleh obyek yang manarik perhatian bagi seseorang akan menjadi faktor penentu internal yang benar-benar mendasar dalam mempengaruhi perhatiannya dan menentukan sikapnya terhadap obyek yang diperhatikan.

Minat merupakan salah satu faktor yang dapat mempengaruhi sikap seseorang dalam mengambil keputusan. Seorang siswa yang memiliki minat bekerja menjadi teknisi otomotif sudah barang tentu minatnya tersebut akan membantu siswa dalam mengambil keputusan untuk bekerja menjadi teknisi otomotif. Sikapnya terhadap pekerjaan teknisi otomotif menjadi positif. Ketika sikapnya positif terhadap pekerjaan maka siswa cenderung merasa senang dengan pekerjaan yang dipilihnya.

\section{KESIMPULAN}

Minat untuk bekerja menjadi teknisi otomotif di kalangan siswa kelas XII TKR SMK Negeri 1 Cilaku tergolong ke dalam kategori tinggi atau baik. Artinya secara umum keseluruhan siswa meminati menjadi seorang teknisi otomotif. Sikap siswa terhadap pekerjaan teknisi otomotif tergolong kedalam kategori tinggi atau positif. Artinya secara keseluruhan siswa memiliki sikap yang positif terhadap pekerjaan teknisi otomotif. Terdapat hubungan positif dan 
signifikan antara minat menjadi teknisi otomotif dengan sikap terhadap pekerjaan teknisi otomotif pada siswa.

\section{DAFTAR PUSTAKA}

Azwar, S. (1997). Sikap Manusia Teori dan Pengukurannya. Yogyakarta: Pustaka Pelajar.

Cosynook. (2013). Teori Minat. [Online]. Tersedia: http://cosynook.wordpress.com/ 2013/02/14/teori-minat/. [2 Juli 2013].

Surya, M. (1979). Pengaruh Faktor-Faktor Non Intelektual Terhadap Gejala Berprestasi Kurang. Desertasi FPS IKIP Bandung: Tidak diterbitkan.

Hariyanto. (2010). Pengertian minat. [Online]. Tersedia: http://belajarpsikologi.com/ pengertianminat. [25 Mei 2013].

Suparyanto. (2011). Konsep Dasar Minat. [Online]. Tersedia: http://drsuparyanto.blogspot.com/ 2011/09/konsep-dasar-minat.html. [26 Juni 2013]. 